\title{
Incompetent Construction Technologies and Resources in the Construction Industry of Yemen
}

\author{
Basil Sultan ${ }^{1}$ and Wa'el Alaghbari ${ }^{2}$
}

Received October 8, 2012 / Revised August 26, 2013 / Accepted January 14, 2014

\begin{abstract}
The Construction industry in Yemen confronts many development constraints, such as the inadequate implementation of appropriate building materials and labour construction technologies. Thus, this research looks over building materials and labour construction technologies used on the local housing construction projects by verifying the percentage of construction expenditure consumed by the main construction components (Materials, Labour and Overhead and Profit), along with the implemented construction technologies. The paper conducts a survey to acquire the cost distribution of the construction main components. The outcomes of the survey were discussed; the discussion was supported by literature on similar issues from some countries. The outcomes confirmed the relatively limited percentage in labour cost and profit, and the elevated percentage of construction materials cost, which are because of the excessive and inappropriate use of materials. What's more, established that the excessively redundant unskilled labours are not effectively engaged in the construction activities, this is due to the tendency of the market in using labour-base technologies. This paper is to recommend a suitable policies and strategies has to be used to decrease cost by using efficiently appropriate construction practice and local materials, moreover take advantage of excessive labour to reduce unemployment.
\end{abstract}

Keywords: Construction industry, building, materials, labour, technology, cost, Yemen.

\section{INTRODUCTION}

Similar to many developing countries, The Construction industry in Yemen confronts many development constraints, such as the inadequate implementation of appropriate building material and labour construction technologies. These constraints become challenging conditions in Yemen. However, the inadequacy in implementing appropriate building material and labour construction technologies, which is affecting the efficiency of the construction process, is barely investigated.

Generally construction consumes up to $90 \%$ of the initial expenditure in the overall process of a project (UNCHS, 1984). This phase, which incorporates the majority of technologies used in construction can be broken down into several steps, each with a unique mix of labour, equipment and materials, and each having technological flexibility. Also it is known that the construction process needs resource inputs such as building materials and supplies; labour of various types and levels of skill; equipment; and finance.

The construction activity in most national income economic records is generally expressed as the valueadded by construction, which generally simply takes in labour costs, overheads and profit; this definition is considered by some as narrow, where here value-added by construction here is only a small part of the total construction process; Drewer (Drewer, 1980) and Wells (Wells, 1986) added that a large percentage of total construction output also consists of the intermediate inputs from other sectors of the economy, mainly the building materials.

The backward linkages of the construction industry to other industries are relatively strong and in fact represent a value, which in most cases exceeds the value-added by the construction sector itself. In developing countries the average value-added by construction accounts for $45 \%$ of total output value, and that intermediate consumption accounts for the remaining 55\% (UNCHS, 1984) and Sultan \& Kajewski (2006). The importance of this issue is that $50 \%$ to $60 \%$ of the total costs of dwellings are for building materials.

Construction consumes most of the initial expenditure in a project, also embraces the majority of technologies used in construction, which can be broken down into several stages, each with a unique mix of labour, equipment and materials. Hence, this paper attempts to look over the local industry by measuring the percentage of construction expenditure consumed by the main construction components (Materials, Labour and Overhead and Profit) and in conjunction with the implemented construction technologies.

\section{RESOURCES REQUIRED BY CONSTRUCTION}

Construction industries in developing countries need resource inputs such as building materials and supplies; labour of various types and levels of skill; equipment; and finance. Table I gives the range of the intermediate

\footnotetext{
${ }^{1}$ Assistant Professor, Project Management, Civil Engineering Department, Faculty of Engineering, University of Sana'a, P.O. Box: 16363, Sana'a, Yemen, baselsultan@yahoo.com

2 Assistant Professor, Project Management, Architecture Department, Faculty of Engineering, University of Sana'a, P. O. Box: 16363, Sana'a, Yemen, wail42311@yahoo.com (*Corresponding Author).
} 
consumption of materials and supplies, which is ranged from $37 \%$ to $55 \%$ of the total value of construction output, and that the wages and salaries paid to construction labour accounted for another $19 \%$ to $27 \%$ in most developing countries (UNCHS, 1984).

The other major component of cost in the construction process is the overhead and profit, the mix of which varies not only among the different steps of construction but also between the various types of construction, project size and construction technologies and moreover the quality of the final product.

TABLE I

THE RANGE OF COMPONENTS OF COST IN THE CONSTRUCTION PROCESS

\begin{tabular}{c|c}
\hline Component & $\%$ \\
\hline Materials & $37-55$ \\
\hline Labour & $19-27$ \\
\hline Overhead and Profit & $44-18$
\end{tabular}

Sources: UNCHS 1984, Sultan and Kajewski (2006) and Sultan (2008a)

Table II gives the breakdown of house construction costs by elements in some developing countries, which indicates the high expenditure in materials, and the relatively low expenditure on labour and profit.

TABLE II

BREAKDOWN OF HOUSE CONSTRUCTION COSTS BY ELEMENTS

\begin{tabular}{c|c|c|c}
\hline & Materials & Labour & $\begin{array}{c}\text { Overhead } \\
\text { and profit }\end{array}$ \\
\hline Ethiopia & $63 \%$ & $20 \%$ & $17 \%$ \\
\hline Kenya & $70 \%$ & $25 \%$ & $17 \%$ \\
\hline Ghana & $47 \%$ & $39 \%$ & $14 \%$ \\
\hline Senegal & $58 \%$ & $24 \%$ & $18 \%$ \\
\hline
\end{tabular}

Sources: UNCHS (1984) and Sultan \& Kajewski (2006)

The major constraint to full capacity utilization in these countries appears to be (UNCHS, 1984) and Sultan \& Kajewski (2006):

- Labour management problems,

- Difficulty in sourcing materials,

- Inefficiency in using resources

- The lack of efficient demand to support the existing capacity,

- Uncontrolled excessive activities by the informal sector, and

- The lack of operating capital as the main financial problem.

The major pressure in Yemen was and still is the rapid pace of change from the traditional to modern and conventional building methods and materials. Recent records, moreover, has demonstrated that it is difficult for the local construction industry to manage and deal with the vast and rapid growth in modern forms of construction that have occurred over the past decades. The construction boom and rapid urbanization have also resulted in a shortage of skilled labour and construction materials. The inadequacies of building materials as well as inadequacies in design and project management potential have been a further hindrance. A lack of any approved national system of codes or standards have only compounded the industries problems (UNIDO/World Bank, 1984) and Sultan and Kajewski (2006).

In brief, the construction activities in Yemen experiencing excessive waste and high costs, however, construction contribution remains low and value added in construction only $3.4 \%$ in 2003 . The abundance of labour are not been taken to the full extent, moreover, the reliance imported materials is mounting. These are due to the unclear inappropriate and inefficient construction practices and technologies strategies (Sultan \& Kajewski, 2003, 2004 \& Sultan, 2008a, 2008b \& 2009). All with a shortage of adequately professional and skilled personnel at all levels of management and field operations amongst clients, contractors and consultants in the construction industry in developing countries and Yemen (Sultan \& Kajewski,(2003), cited by Aized H. Mir et al, (2007).

The paper starts by reviewing the current labour and material resources, along with the building technologies used in the local construction industry of Yemen. The paper then conducts a survey to obtain the cost distribution of the construction main components, as well as, to identify the building material and labour construction technologies used in the housing projects. The outcomes of the survey are discussed, and comparisons from literature on similar issues in some developing countries are made for assessing the situation and drawbacks of the local industry. On view of that, appropriate recommendations are proposed to improve the situation.

\section{METHODOLOGY}

It should first be emphasised that the objective was to outline the existing issues related the local material and labour resources in construction sector of Yemen and then formulate the essential list of recommendations for development in the construction industry. In order to achieve the objective of this study, a three-step approach was followed in the methodology. These steps as follow:

- Literature and Data collection

- Survey on the local industry and

- Discussions

\section{A. Literature and Data Collection}

Literature and data collection was performed to recognize the existence of the problem in current construction industry practices and technologies.

Yemen was considered an exporter of unskilled labour (Fergany, 2001; ESCWA, 1993). As construction booms began in the gulf countries in the 1960s and 1970s, labour was attracted from throughout the region, including Yemen (Fergany, 2001; ESCWA, 1993). In 1975, about 280,000 Yemenis were working outside the country, remitting some US\$375 million annually. In 1979, this remittance rose to US\$1.5 billion (Kulkarni, 1983). This introduced a paradoxical situation in which Yemeni 
workers found employment abroad is more profitable. These Yemeni labour emigrants between 1973 and 1983 reached about 470,000 and consisted mainly of unskilled construction workers. The national exchanger gained much needed foreign exchange for development, but the nation lost its pool of skilled workers and human resources.

In the late $1980 \mathrm{~s}$ when the construction booms in neighbouring countries ended, the demand for the Yemeni labour decreased substantially (ESCWA, 1993). It was estimated that approximately 800,000 Yemenis returned only from Saudi Arabia (ILO, 1991). Of these, $11.3 \%$ were construction workers and $13.9 \%$ were unskilled labour (Colton, 1993). It was expected that those labourers who returned would bring with them valuable experience. However, recent history has demonstrated, that it was not possible for the local Yemen construction industry to cope with the rapid growth needed for the modern forms of construction ${ }^{1}$ (Figure I) that have occurred over the past decades Sultan \& Kajewski (2003, $2004 \& 2005)$ and Sultan (2008a \& 2008b).

Despite the excessive labour it can be suggested that the construction industry has not used the full capacity of the excessive labour market. Table III below outlines the moderate labour employment of around $6.0 \%$ in the construction industry in Yemen.

TABLE III EMPLOYMENT IN CONSTRUCTION

\begin{tabular}{c|c|c|c}
\hline & 1975 & 1990 & 2001 \\
\hline Yemen & $4 \%$ & $7.5 \%$ & $6.6 \%$ \\
\hline Average Developing Countries & \multicolumn{3}{|c}{$5 \%-15 \%$} \\
\hline
\end{tabular}

Source: UNCHS (1984), ESCWA (1993), World Bank (2002) and Sultan \& Kajewski (2006).

The fact unskilled labours are abundant in developing countries; moreover, there tends to be a shortage of skilled labours. The data in Table IV, which extracted from a UNCHS report (UNCHS 1984), indicates the existence of excessive unskilled labour market in Yemen, with low number of craftsmen, and absence of management (including site supervision and administrative personnel).

According to the World Bank (2002), the underemployment rate in 2002 was $25 \%$. Unemployed workers emerged from all sectors of the economy, the highest being in construction $(20 \%)$ followed by transport $(9.6 \%)$, industry $(8.8 \%)$, trade $(8.4 \%)$ and agriculture $(6.6 \%)$.

Despite the high scale of unskilled labour (Table IV), the employment in Construction, as indicated in (Table III) is relatively low. The reasons can be that labour technologies, such as labour-intensive ${ }^{2}$ methods in

\footnotetext{
${ }^{1}$ Modern construction refers to buildings that built recently in Yemen, mostly in cities and towns. In these urban areas, constructions are frequently carried out using imported modern techniques, and whose main characteristic is the structural reinforced concrete frame. The external walls of structural reinforced concrete frame buildings housing units are made of cement blocks or local stones to simulate the traditional style a kind of modern/traditional, which is expensive.

${ }^{2}$ Labour-intensive Projects or approaches where labour is the
}

Yemen are not efficiently utilised nor managed, moreover, labour-intensive methods has not been encouraged nor appropriately introduced by the local industry or by the correlated government policies, moreover, the local market simply considers labour-intensive methods as expensive, time consuming and difficult to control.

TABLE IV

ITEMISATION OF LABOUR FORCE IN CONSTRUCTION BY LABOUR CATEGORY IN YEMEN

\begin{tabular}{l|c}
\multicolumn{1}{c}{ Category } & Yemen \\
\hline Unskilled labour & $83 \%$ \\
\hline Craftsmen and skilled labour & $7 \%$ \\
\hline Administrative and clerical & - \\
\hline Professional & $\begin{array}{c}9 \%(7 \% \text { mid level 2\% high } \\
\text { level) }\end{array}$ \\
\hline Management & - \\
\hline \multicolumn{2}{c}{ Source: UNCHS (1984), Sultan and Kajewski (2005 \& 2006) }
\end{tabular}

Serageldin (1982) has indicated that the modern constructionin urban areas were often carried out using modern techniques. The relatively expensive and inefficient labour-intensive methods with low productivity have led contractors to invest in labourbased $^{3}$ construction.

Alaghbari (2010) and Alaghbari et al. (2012) found that materials costs were in the top significant factors influencing construction costs in Yemen. These materials were steel for reinforced concrete and cement. This is because most of materials used in construction industry in Yemen were imported which also is affecting by economic condition and exchange rate.

Additionally, regarding to construction methods that used in Yemen, Alaghbari et al. (2012) identified that the concrete frame system preferred to be used in Yemen while the conventional method system still used widely. Although the concrete frame is one of the significant factors influencing construction costs in Yemen that is because of steel and cement costs. dominant resource for carrying out the works, and where the share of the total project cost spent on labour is typically high i.e. $50-60 \%$ (I.L.O.).

${ }^{3}$ Labour-Based Technology A construction technology which aims to apply a labour/equipment mix that gives priority to labour, but supplements labour with appropriate equipment where necessary for reasons of quality or cost. It is a supervision-intensive system. The term incorporates the idea of optimising the mix of labour and equipment to produce a cost-effective result (International Labour Organization, I.L.O) 


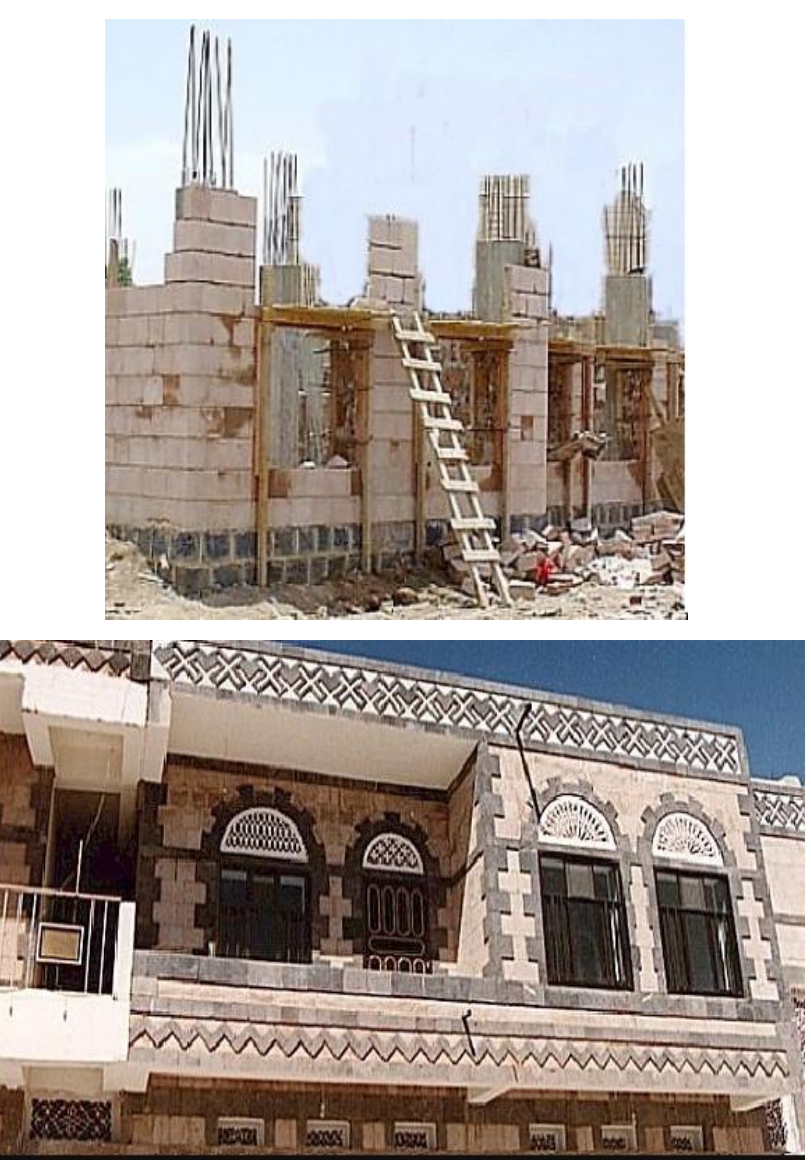

FIGURE I

Modern/TRAditional CONSTRUCTION, Reinforced CONCRETE FRAME WITH LOCAL STONES CLADDING (PICTURES WERE TAKEN BY AUTHORS IN 2011)

\section{B. Survey On The local industry}

Due to the lack of any existing local data or research on construction technologies, it was necessary to conduct a local survey on the construction industry; this is to provide some insight into this area. It was envisaged that the results obtained would generate some helpful information on the various recurrent issues on the construction technologies. Data, views and knowledge of the stakeholders and professionals in the construction industry was scrutinized and collected using a structured survey. The survey questionnaire was distributed to selected professionals and stakeholders operating in the capital city of Yemen Sana'a as well as in Aden city. While the choice of the survey location was mainly in the capital city of Sana'a, where major construction and economic activities including the construction of informal housing units are taking place, the participants were in fact from different parts of the country and are currently working in the capital. Therefore, the survey unintentionally embraced other parts of Yemen.

However the main information required on construction practices, as experienced by the local contractors and stakeholders are:

- The distribution (breakdown) of construction cost, and

- The construction technologies and methods that are used in the execution of local construction projects.
From 219 a total number of construction industry companies registered in the Ministry of Public Works and Roads in Yemen, where 70 companies selected randomly.

These responses represented a wide range of stakeholders who have been involved in construction activities including the construction of informal housing units, as well as experienced engineers working privately in small to medium size consulting and contracting construction firms or on government projects. From 70 questionnaires distributed by hand, a total of 49 responses were received and 5 of which have been discarded for being incomplete, making it a total of 44 participants (62.86\% of 70 questionnaires).

The respondents were asked to give their estimate on the proportion of cost distribution on materials, labour and profit as experienced in the local market. The average survey outcomes were tabulated in Table V. The average materials cost in Yemen according to the survey consumes up to $61.6 \%$, in some individual cases consumes up to $70 \%$ of the total cost.

TABLE V

BREAKDOWN OF HOUSE CONSTRUCTION COSTS BY ELEMENTS IN YEMEN

\begin{tabular}{c|c|c}
\hline $\begin{array}{c}\text { Materials and } \\
\text { Supplies }\end{array}$ & On-site labour & Overhead and profit \\
\hline $61.6 \%$ & $22 \%$ & $16.4 \%$ \\
\hline
\end{tabular}

The participants were also asked to indicate the construction labour technologies used in the execution of construction projects. The responses indicated that the majority of the stakeholders $(73.6 \%)$ were actually use labour-based ${ }^{4}$ construction methods and only $26.4 \%$ of the stakeholders use labour-intensive and capital methods. The average survey outcomes were tabulated in Table VI

TABLE VI

CONSTRUCTION LABOUR TECHNOLOGIES USED IN YEMEN

\begin{tabular}{c|c|c}
\hline Labour-based & labour-intensive & Machine/capital \\
\hline $73.6 \%$ & $26.4 \%$ & - \\
\hline
\end{tabular}

\section{Discussions}

Previous studies on the local industry has pointed out to the major constraints to the construction industry development, and pointed to the high construction waste and cost that are related mainly to the inappropriate construction practices, anyhow, a survey on the local industry was performed by (Sultan \& Kajewski, 2003 \& 2004) has recognized that the most important factors causing high construction costs were identified as imported materials, inflation and unstable economy and excessive construction waste.

\footnotetext{
${ }^{4}$ Labour-Based Technology: A construction technology which aims to apply a labour/equipment mix that gives priority to labour, but supplements labour with appropriate equipment where necessary for reasons of quality or cost. It is a supervision-intensive system. The term incorporates the idea of optimising the mix of labour and equipment to produce a cost-effective result (International Labour Organization ILO)
} 
Alaghbari et al., (2012) and Alaghbari (2010) clarified that the most significant factors influencing construction costs were steel, cement, economic condition and exchange rate. Moreover, the most materials used in construction industry in Yemen are imported, which are influenced by economic condition, and shipping and insurance costs.

Sultan \& Kajewski (Sultan \& Kajewski, 2003 \& 2004) also indicated that some of the specific difficulties associated with the Yemen's construction industry, are mainly the unclear and none unified construction technologies and methods and the regulations that control the construction process. This has created a tendency in the project's owners to minimize their construction costs by eliminating or minimizing the technical and engineering assistance in design and supervision. This tendency has only led to the over-designs, excessive use and site waste of construction materials and quality concrete of the specified strength is not frequently produced due to that the operation is not properly supervised.

Other studies have concluded that administrative and legal institutional improvement and appropriate construction regulations are essential requirements to overcome the technical and economical constraints in the construction industry development (Sultan \& Kajewski, 2004, 2005 \& 2006). Moreover, Sultan (2008a, 2008b) pointed out to the need of appropriate construction practices and technologies to achieve any development.

The surveys on the local industry performed by Sultan \& Kajewski (2003, 2004, 2005 \& 2006) have recognized the technical barriers and economic bottlenecks facing the local industry development. The general conclusion on the barriers of development came as institutional and administrative weakness, in all forms of bureaucracy and corruption, followed by the lack of infrastructure required for economic activities and human settlements integration and well-being, third was law and legal matters followed by financial and funding issues.

Therefore the general construction situation can be summarized as follows Sultan \& Kajewski (2003, 2004, 2005 \& 2006), Sultan (2008a, 2008b), Alaghbari (2010) and Alaghbari et al. (2012):

- Low quality and high costs in all housing projects

- Uncontrolled and low quality activities and products

- Unclear procedure in obtaining permissions and designs acceptance

- Excessive informal activities

- Uncontrolled and illegal activities

- High risks, unsupported and unsustainable businesses

- The lack of managerial skills

- Low productivity and high time and cost overruns and

- Unclear and inappropriate construction practices \& technologies

The result of the survey analysis found that in modern and modern/traditional housing projects in Yemen, the average materials cost consumes up to $61.6 \%$, and in some cases participants recorded up to $70 \%$ of the total construction expenditure spent on materials which is high; where the average value is $37-55 \%$ according to the UNCHS (see Table I). These high costs spent on materials leave little expenditure margins to comfortably manoeuvre between labour and profit. This high materials' expenditure is most definitely because of the high expenses spent on the conventional materials, moreover, due to the excessive waste caused by the misuse of materials and by inefficient implementation of unclear imported building practices and technologies in all modern projects. Furthermore, that most materials used in construction industry in Yemen are imported.

At the same time the contractors' overhead and profit is found to be limited only to $16.4 \%$; where the average profit according to the UNCHS is $18-44 \%$ (see Table I). This low profit is due to many reasons mainly to the lack of managerial skills in terms of keeping the project within the schedule and cost. Nonetheless, large amounts of this overhead and profit expenditure is in fact is consumed by the overhead costs including hidden expenses and indirect costs, which are usually missed out and not considered by most contractors, thus leaving them with low or negative earnings. Consequently, contractors faced with market's high risks ${ }^{5}$; which always forces contractors to quit the contracting business, or as in most cases, contractors to deliberately provide low quality products to compensate for their low returns.

On top of the previous drawbacks, the shortage of managers and supervisors has driven contractors and the local market to use plant and equipment (labour-based technologies) to replace the technically and financially hazardous unskilled labour activities.

\section{SUMMARY}

This paper has outlined the current construction practices and technologies utilised inefficiently in Yemen. These construction practices are assessed through the distribution of cost in the three main construction components (Materials, Labour and Overhead and Profit).

The distribution of cost established via survey, which confirmed the relatively limited percentage in labour cost and profit and high percentage of construction materials cost, which are due to excessively and inappropriately using building materials practices. In addition, labours are not adequately employed due to using labour-base technologies.

To improve the situation suitable policies and strategies has to be used to decrease cost by using efficiently appropriate local building materials and construction practices and, moreover take advantage of the excessive labour to reduce unemployment and as a whole increase the contribution of the industry to the economy.

\section{CONCLUSIONS}

As being established that, there are requirements for serious strategies and policies to initiate technical and

\footnotetext{
${ }^{5}$ market's high risks mainly due to discontinuity of work, excessive informal activities and unstable prices
} 
economical development in Yemen. As suggested by Coukis and Grimes (Coukis \& Grimes, 1980) some developing countries have promoted labour-intensive construction to provide social and economic advantages for the population, even though this procedure could hinder the quality and completion of the construction projects. Similarly to achieve some improvement were done by Andrews et al, (1972) and Hillebrandt, (1997) who have recommended that labour-intensive types of construction should be chosen so that the abundant unskilled labour could be used, thus economizing on imported equipment and materials. Hillebrandt recommended that large projects should be broken down into smaller jobs to enable medium-size contractors to gain experience on projects that they could handle.

Nevertheless, (Sultan \& Kajewki, 2004, 2005 \& 2006) indicated that local experts did not vigorously pursue the labour-intensive policy, to promote some local economic sustainability in employment in Yemen. This is due to low the productivity, high cost and management problems associated with the labour-intensive policy programmes.

Also findings on previous investigations on Yemen and discussions with the experts, on development policies, process requirements and recommendations for the construction industry in Yemen has concluded that a policy of local materials protection was not strongly recommended (Sultan \& Kajewki, 2004, 2005 \& 2006). This is in view of the fact that the construction industry in Yemen is very dependent on the imports of construction materials; where imported materials comprise $60 \%$ to $70 \%$ percent of the construction costs in the modern sector in Yemen (Miles, 1984); thus, the material industry is not ready to for an immediate takeover to fulfil the market demands.

However, the following recommendations can be formulated for the construction industry in Yemen:

- Proper construction technologies should be clearly selected to suite the available resources and skills.

- Labour input in construction should be improved by adopting those technologies that are relevant and suitable to the available local resources and skills.

- The utilisation of indigenous construction related resources should be optimised by adopting those technologies and practices that are relevant

- The local contractors should be supported and protected by government through appropriate training and pilot jobs

- Efficient labour intensive management of labour or human resources can be a key to a successful construction process.

- Initiate more research on the use of local materials and the recommended measures for their development.

- The construction material industries should be adjusted and controlled by adequate choice and implementation of policies and strategies that balance local industry protection and open markets policies.

- Construction regulations and laws should be positively influence the choice and quality of the construction practices (Sultan \& Kajewki, 2005 \& 2006),

- Institutional and administrative and human development should be advocated to facilitate and monitor any required development (Sultan \& Kajewki, 2005 \& 2006).

- To tolerate the adaptation of any appropriate strategies and policies required for reducing the impact of unemployment and taking advantage of the excessive local labour, Managerial skills in construction projects should be promoted and human training enhanced,

\section{REFERENCES}

[1] W. Alaghbari, "Controlling the Cost of Affordable Housing for Low-income Group: Factors Affecting Construction Costs in Affordable Housing for Low-income Group in Sana'a, Yemen", LAMBERT Academic Publishing, Germany, 2010.

[2] W. Alaghbari, A. Salim, K. Dola, A.A.A. Ali, "Identification of significant factors influencing housing cost in Yemen", International Journal of Housing Markets and Analysis, vol. 5 no. 1, pp. 41-52, 2012.

[3] J. Andrews, M. Hatchett, P.M. Hillebrandt, A.J. Jaafar, S. Kaplinsky, H. Oorthuys, "Construction in Overseas Development: A framework for Research and Action", University College London Environmental Research Group, London, 1972.

[4] N.A. Colton, "Homeward Bound: Yemeni Return Migration", International Migration Review, vol. 27, no. 4, pp. 870-882, 1993.

[5] S. Drewer, "Construction And Development: A New Perspective", Habitat International, vol. 5, no. 3/4, pp. 395-428, 1980.

[6] ESCWA Economic and social Commission for West Asia, "The Absorption of returnees in the Republic of Yemen. In Return Migration profiles, Impact and Absorption in Home Countries", E/ESCWA/SD/1993/12, ESCWA, New York, 1993.

[7] N. Fergany, "Aspects of Labor Migration and Unemployment in the Arab Region", 2001. (Retrieved in October 2002: http://www.worldbank.org/mdf/mdf4/papers/fergany.pdf)

[8] P. Hillebrandt, "Problems of, and Some Remediesfor, Some Underdeveloped Construction Industries", Proceedings of the $1^{\text {st }}$ International conference on construction industry development, Building the Future Together, Singapore, 1997.

[9] International Labour Office (ILO), "Migrant Workers Affected by the Gulf Crisis", Report of the Director General, $3^{\text {rd }}$ supplementary report, GB.249/15/7. 27 $7^{\text {th }}$ February- $2^{\text {nd }}$ March, 1991.

[10] International Labour Office (ILO), "Labour-Based Technology", 2004. (Retrieved in October 2002: http://www.ilo.org/public/english/employment/recon/eiip/asist/abo ur/index.htm)

[11] B.V. Kulkarni, "A Construction Industry in Transition", in Development and Urban Metamorphosis; Volume 1: Yemen at the Cross-Roads, Eds. A. Evin, Singapore: Concept Media/The Aga Khan Award for Architecture, 1983.

[12] D. Miles, "Yemen Arab republic: the construction industry", in Development and Urban Metamorphosis; Volume 2: Background Papers, Eds. A. Evin, Singapore: Concept Media/The Aga Khan Award for Architecture, 1984

[13] A.H. Mir, M. Tanvir, A.Z. Durrani, "Development Of Construction Industry - A Literature Review", Report No. 43185, Pakistan Infrastructure Implementation Capacity Assessment (PIICA), South Asia Sustainable Development Unit (SASSD), 2007. (Retrieved in October 2002: http://wwwwds.worldbank.org/external/default/WDSContentServer/WDSP/I B/2008/04/24/000333038_20080424013721/Rendered/PDF/43185 OPNTOREPL10A0Literature0Review.pdf)

[14] I. Serageldin, "Rural Architecture in the Yemen Arab Republic: The Impact of Rapid Economic Growth on Traditional Expression", in The Changing Rural Habitat; Volume I: Case Studies, Eds. B.B. Taylor, Singapore: Concept Media/The Aga Khan Award for Architecture, 1982.

[15] B. Sultan, "The Informal Construction Sector in Yemen", Proceedings of Aden University $2^{\text {nd }}$ Conference on Building, $12^{\text {th }}$ March, 2009. 
[16] B. Sultan, "Structural and Finishing Costs in Yemen", Proceedings of International Conference in Building Education and Research (BEAR) CIB W89, Kuala Lumbur, Malaysia, $16^{\text {th }}-20^{\text {th }}$ June, 2008a

[17] B. Sultan, "Modern /Traditional Buildings in Yemen and Sustainability", Proceedings of the University of Aden Conference, $28^{\text {th }}-30^{\text {th }}$ January, 2008b.

[18] B. Sultan, S. Kajewki, "Requirements for Economic Sustainability in the Yemen Construction Industry", Proceedings of the CIB Working Commission W107, Construction in Developing Economies, International Symposium on Construction in Developing Economies, Santiago, Chile, $18^{\text {th }}-20^{\text {th }}$ January, 2006.

[19] B. Sultan, S. Kajewki, "Policies for Economic Sustainability for the Construction Industry in Yemen", Proceedings of the $3^{\text {rd }} \mathrm{CIB}$ Student Chapters International Symposium, $4^{\text {th }}-8^{\text {th }}$ July, Queensland University of Technology, Brisbane, Australia, 2005.

[20] B. Sultan, S. Kajewki, "Local Problems in the Construction Industry of Yemen", Proceedings of International Symposium on globalization and Construction, W107 Construction in Developing Economies, Bangkok, Thailand, $17^{\text {th }}-19^{\text {th }}$ November, 2004.

[21] B. Sultan, S. Kajewki, "The Yemen Construction Industry: Readying the Industry for the Successful Implementation of Sustainability", Proceedings of the CIB 2003 International Conference on Smart and Sustainable Built Environment (SASBE2003), Brisbane, Australia, $19^{\text {th }}-21^{\text {st }}$ November, 2003a.

[22] B. Sultan, S. Kajewki, "The Behaviour of Construction Costs and Affordability in Developing Countries: A Yemen Case Study", Proceedings of Knowledge Construction Joint International Symposium of CIB Working Groups W55, W65 and W107, Singapore, $22^{\text {nd }}-24^{\text {th }}$ October, 2003b

[23] UNCHS United Nations Centre for Human Settlements, "The Construction Industry in Developing Countries", Contribution to socio-economic growth, Nairobi, 1984.

[24] UNIDO United Nations Industrial Development Organization, WBCP World Bank Cooperative Programme, "Yemen Arab Republic: The Construction Industry", Report no. 17, Vienna, 1981.

[25] J. Wells, "The Construction Industry in developing countries: Alternative Strategies for Development", Croom Helm Ltd., London, 1986.

[26] WB World Bank, "The Republic of Yemen Economic Growth: Sources, Constraints and Potentials", Report No. 21418-YEM, Social and Economic Development Group, Middle East and North Africa MENA Region, Development Group, 2002. (Retrieved in August 2003: http://lnweb18.worldbank.org/mna/mena.nsf/Attachments/Growth 2002/\$File/Growth-letter.pdf)

[27] WB World Bank, "The Construction Industry: Issues and Strategies in Developing Countries", International Bank for Reconstruction and Development, World Bank, Washington, D.C., USA, 1984.

[28] WB World Bank, "The Republic of Yemen - Economic Growth: Sources, Constraints and Potentials", International Bank for Reconstruction and Development, World Bank, Washington, D.C., USA, 2002a. 